ISSN: 2338-4328 (Print), ISSN: 2686-2646 (Online)

\title{
ANALISIS FAKTOR YANG MEMPENGARUH KUALITAS LAPORAN KEUANGAN BUMDES SEKECAMATAN PASIR PENYU KABUPATEN INDRAGIRI HULU
}

\author{
Walmi Sholihat $^{1)} *$, Fatti Corrina ${ }^{2)}$ \\ ${ }^{1}$ Program Studi Manajemen, STIE Indragiri, Rengat \\ ${ }^{2}$ Program Studi Manajemen, STIE Indragiri, Rengat \\ *E-mail: ${ }^{1}$ walmisholihat@ stieindragiri.ac.id, ${ }^{2}$ fatticorrina@ stieindragiri.ac.id
}

\begin{abstract}
Abstrak
Secara umum laporan keuangan BUMDes tidak berbeda jauh dengan laporan keuangan lembaga lainnya seperti Neraca, laporan Laba/ Rugi serta Laporan Perubahan Modal. Laporan keuangan dibutuhkan untuk mengungkap kinerja keuangan BUMDes secara keseluruhan sepanjang satu periode. Dari delapan BUMDes yang ada di Kecamatan Pasir Penyu seluruhnya belum lengkap dalam pelaporan keuangan. Metode analisis yang dilakukan dengan uji hipotesis yang melibatkan 40 orang responden yang didapat dari Perangkat Desa dan Anggota BUMDes Sekecamatan Pasir Penyu Kabupaten Indragiri Hulu. Setelah dilakukan Uji Hopotesis dan didapat bahwa Tingkat Pendidikan, Pengalaman Kerja, dan Pelatihan mempengaruhi Kualitas Laporan Keuangan BUMDes Sekecamatan Pasir Penyu Kabupaten Indragiri Hulu.
\end{abstract}

Kata kunci: Kualitas Laporan Keungan, Tingkat Pendidikan, Pengalaman Kerja, Pelatihan

\section{ANALYSIS OF FACTORS AFFECTING THE QUALITY OF FINANCIAL STATEMENT OF BUMDES IN PASIR PENYU DISTRICT, INDRAGIRI HULU REGENCY}

\begin{abstract}
In general, the financial statements of BUMDes are not much different from the financial statements of other institutions such as the Balance Sheet, Income Statement and Statement of Owner Weuity. Financial statement are needed to reveal the overall financial performance of BUMDes over a period. Of the eight BUMDes in Pasir Penyu District, all of them are incomplete in financial statement. The method of analysis was carried out by testing the hypothesis involving 40 respondents obtained from the Village Apparatus and BUMDes Members of the Pasir Penyu District, Indragiri Hulu Regency. After the hypothesis test was carried out, it was found that the level of education, work experience, and training affected the quality of the financial statements of BUMDes in Pasir Penyu District, Indragiri Hulu Regency.
\end{abstract}

Keywords: Quality of Financial Statement, Education Level, Work Experience, Training 


\section{SULTANIST: Jurnal Manajemen dan Keuangan, Vol 9 (2), Desember 2021}

\section{PENDAHULUAN}

Laporan keuangan tidak lepas dari kedudukan ilmu akuntansi, dimana buat tersajinya laporan yang baik serta benar dibutuhkan kedudukan akuntan yang mempunyai kompensi yang mempuni. Laporang Keuangan yang biasa disajikan antara lain laporan laba rugi, neraca, laporan pergantian modal, laporan arus kas, serta catatan serta laporan lain dan modul uraian yang ialah bagian integral dari laporan keuangan (PSAK 2015). Disamping itu pula tercantum skedul serta data bonus yang berkaitan dengan laporan tersebut, misalnya, data keuangan segmen industri serta geografis dan pengungkapan pengaruh pergantian harga. Oleh sebab itu, kompetensi SDM ialah salah satu aspek yang memastikan suatu laporan keuangan tersebut bermutu ataupun tidak. Kompetensi merupakan karakteristik seorang yang bisa dilihat dari keahlian, pengetahuan, serta keahlian yang dimilikinya dalam perihal menuntaskan tugas- tugas yang dibebankan kepadanya(Hervesi, 2005 dalam Indriasari 2008).

Laporan keuangan sangat berarti dalam sesuatu lembaga pemerintahan ataupun organisasi tertentu sebab bisa dipakai selaku acuan dalam memastikan sesuatu keberhasilan lembaga tersebut. Laporan keuangan merupakan data yang disajikan buat menolong stakeholders dalam membuat keputusan sosial, politik serta ekonomi sehingga keputusan yang diambil dapat lebih bermutu(Mahmudi, 2007: 11). Tujuan dari dibuatnya laporan keuangan merupakan buat bisa membagikan data kepada pihak- pihak yang berkepentingan. Laporan keuangan pula bisa dipakai selaku bawah pengambilan keputusan lembaga sehingga bisa menciptakan sesuatu data yang profesional serta bisa dipercaya. Buat itu, laporan keuangan yang terbuat sebaiknya wajib bermutu serta mudah dimengerti, relevan, dan andal.

Seluruh entitas telah diharuskan menyajikan laporan keuangan minimun per satu tahun sekali, baik entitas berskala besar ataupun entitas kecil sekelas Badan Usaha Milik Desa. Bumdes ialah bentuk usaha yang dikelola desa yang menyelenggarakan aktivitas bisnis dengan tujuan profit oriented sehingga desa bisa berdiri sendiri dengan menggunakan sumber daya yang dikelola dengan baik serta benar melalui perantara Bumdes. BUMDes ialah lembaga usaha desa yang dikelola oleh warga serta pemerintah desa dalam upaya menguatkan perekonomian desa serta membangun kerekatan sosial warga yang dibangun bersumber pada kebutuhan serta kemampuan desa(Maryunani, 2008).

Pertumbuhan Bumdes tidak terlepas dari lahirnya Undang- Undang Nomor. 6 Tahun 2014 tentang Desa yang menerangkan bahwa Desa merupakan kesatuan warga hukum yang mempunyai batasan daerah yang berwenang buat mengendalikan serta mengurus urusan pemerintahan, kepentingan warga setempat bersumber pada prakarsa warga, hak asal usul, serta/ ataupun hak tradisional yang diakui serta dihormati dalam sistem pemerintahan Negara Kesatuan Republik Indonesia. Lewat kewenangan asal usul serta kewenangan lokal berskala Desa, Undang- Undang Nomor. 6 Tahun 2014 membagikan kewenangan yang lebih luas kepada Desa buat mengendalikan urusan rumah tangganya. Pemerintah mendesak aktivitas ekonomi warga lewat proses pemberdayaan serta menghasilkan regulasi yang membagikan kesempatan tumbuhnya usaha kecil serta mikro. Kemajuan dibidang ekonomi tidak cuma diprioritaskan untuk daerah perkotaan namun secara menyeluruh 
wajib hingga ke daerah pedesaan. Salah satu metode menggapai perkembangan ekonomi di daerah pedesaan melalui perkembangan lembaga mikro desa serta salah satu lembaga mikro diwilayah pedesaan ialah Badan Usaha Milik Desa(BUMDes).

BUMDes selaku lembaga keuangan desa yang melaksanakan bisnis keuangan (Financial Business) yang memenuhi kebutuhan usaha- usaha skala mikro yang dijalankan oleh pelakon usaha ekonomi desa, BUMDes harus membuat laporan keuangan seluruh unit usaha BUMDes secara akuntabel serta transparan yang dibuat tiap bulannya. Tidak hanya itu, BUMDes pula harus membagikan laporan pertumbuhan unit- unit usaha BUMDes kepada warga desa lewat musyawarah desa yang sekurang- kurangnya 1 kali dalam satu tahun. Laporan keuangan menyediakan data yang relevan tiap posisi keuangan serta segala transaksi yang dilaksanakan oleh sesuatu entitas pelaporan sepanjang satu periode pelaporan.

Secara umum laporan keuangan BUMDes tidak berbeda jauh dengan laporan keuangan lembaga lainnya. Laporan keuangan dibutuhkan untuk mengungkap kinerja keuangan BUMDes secara keseluruhan sepanjang satu periode. Laporan keuangan biasanya terdiri dari neraca, laporan laba/ rugi serta laporan perubahan modal. Dalam penyajian laporan keuangan, wajib disadari bahwa banyak pihak yang membutuhkan data dalam laporan keuangan tersebut. Oleh sebab itu, data keuangan yang tersaji dalam laporan keuangan tersebut wajib berguna untuk para pemakai. Data yang baik apabila data tersebut dapat dimengerti serta bisa digunakan oleh pemakai.

$$
\text { Perkembangan BUMDes di }
$$

Kabupaten Indragiri Hulu cukup pesat, karena setiap desa yang ada di Kabupaten
Indragiri Hulu wajib memiliki Badan Usaha Milik Desa Bumdes. Menurut Dinas Pemberdayaan Masyarakat dan Desa Kabupaten Indragiri Hulu dan hasil prariset peneliti maka ditemukan mulai tahun 2018 $\begin{array}{llllll}\text { hingga } & 2020 & 8 & \text { BUMDes yang ada }\end{array}$ dikecamatan Pasir Penyu belum melakukan pelaporan dengan baik dan belum sesuai dengan kaidah akuntansi yang berlaku umum.

Tabel 1. Daftar BUMDes Sekecamatan Pasir Penyu dan Pelaporan Keuangan Tahun 2020

\begin{tabular}{|c|c|c|c|}
\hline NO & NAMA DESA & NAMA BUMDES & $\begin{array}{c}\text { LAPORAN } \\
\text { KEUANGAN }\end{array}$ \\
\hline 1 & Petalongan & Untung Gemilan & Belum Lengkap \\
\hline 2 & Air Molek II & Layar Berkembang & Belum Lengkap \\
\hline 3 & Pasir Keranji & Maju Bersama & Belum Lengkap \\
\hline 4 & Jatirejo & Jati Makmur & Belum Lengkap \\
\hline 5 & Batu Gajah & Gajah Makmur & Belum Lengkap \\
\hline 6 & Candi Rejo & Candi Makmur & Belum Lengkap \\
\hline 7 & Lembah Dusun Gading & Tunas Mandiri & Belum Lengkap \\
\hline 8 & Serumpun Jaya & Jaya Bersama & Belum Lengkap \\
\hline
\end{tabular}

Dari Tabel 1 dapat disimpulkan bahwa Bumdes Sekecamatan Pasir Penyu hanya membuat pencatatan sederhana dan belum sesuai dengan laporan yang diinginkan oleh pemerintah. Kemudian penyebab permasalahan tersebut diantaranya, data-data yang disajikan tidak sesuai dalam laporan keuangan BUMDes seperti kesalahan pencacatan dan kurangnya ketelitian dari SDM sehingga mengakibatkan terjadinya ketidak seimbangan (balance) pada laporan keuangan BUMDes itu sendiri. Selain itu, dilihat dari tingkat Pendidikan pengurus masih rendah, kurangnya pelatihan dan dimana masih adanya karyawan BUMDes yang merangkap bekerja di tempat lain (Double Job), kurangnya pelatihan-pelatihan yang diadakan dapat dilihat dari jumlah pelatihan yang diadakan setiap tahun cuma 
sekali, yang berkaitan dengan pelaporan BUMdes.

Berdasarkan uraian diatas penulis tertarik mengambil judul penelitian FaktorFaktor yang mempengaruhi Kualitas Laporan Keungan Bumdes Sekecamatan Pasir Penyu dengan Variabel $X$ yaitu Tingkat Pendidikan, Pengalaman Kerja dan Pelatihan sementara Variabel $\mathrm{Y}$ yaitu Kualitas Laporan Keuangan.

\section{LANDASAN TEORI}

\section{Laporan Keuangan}

Laporan keuangan adalah catatan akuntansi suatu entitas pada suatu peride akuntansi yang dapat menggambarkan kinerja entitas tersebut. Laporan keuangn merupakan laporan yang terstruktur mengenai posisi keuangan dan transaksitransakti yang dilakukan oleh suatu entitas pelaporan. Laporan keuangan dapat dikatakan sebagai data dan sebagai informasi. Laporan keuangan pemerintah ditunjukan untuk memenuhi tujuan umum pelaporan keuangan namu tidak untuk memenuhi kebutuhan khusus pemakainya.

\section{Tujuan Laporan Keuangan}

Mahmudi (2011) menyatakan tujuan umum laporan keuangan adalah untuk menyajikan informasi mengenai posisi keuangan, realisasi anggaran, arus kas dan kinerja keuangan suatu entitas pelaporan yang bermanfaat bagi para pengguna dalam membuat evaluasi keputusan mengenai alokasi sumber daya manusia. Secara spesifik, tujuan pelapora keuangan pemerintah adalah untuk menyajikan informasi yang berguna untuk pengambilan keputusan sertamenunjukan akuntabilitas entitas pelaporan sumber daya yang dipercayakan.

\section{Kualitas Laporan Keuangan}

Kriteria dan unsur- unsur kualitas atau niali informasi dari laporan keuangan pemerintah telah ditentukan Standar Akuntansi Pemerintah dalam Peraturan Pemerintah Nomor 71 Tahun 2010 ada empat macam karakterisitik kualitas informasi keuangan yaitu :

a. Relevan,

Informasi dikatakakan relevan apabila informasi tersebut memiliki manfaat dan dapat mempengaruhi pengambilan keputusan manajerial. Informasi yang relevan dapat digunakan untuk mengevaluasi peristiwa masa lalu, masa sekarang dan masa depan (predictive value), dan memperbaiki harapan yang telah dibuat sebelumya (feedback value), serta informasi harus tersedia tepat waktu bagi pengguna informasi untuk pengambilan keputusan (timeliness)

b. Reliable / Andal

Keandalan informasi bergantung pada kemampuan suatu informasi dalam menyajikan secara wajar keadaan atau peristiwa yang disajikan dengan keadaan yang sebenarnya terjadi. Keandalan informasi akan berbadan tergantung pada level pemakai, tingkat pemahaman pada aturan dan standar yang digunakan untuk menyajikan informasi tersebut. Suatu informasi dikatakan andal apabila:

1. Dapat diverifikasi (verifiable)

Suatu informasi diuji kebenarannya oleh orang yang berbeda dengan metode yang sama akan menghasilkan hasil akhir yang sama.

2. Netral

Tidak ada unsur bias dalam penyajian laporan atau informasi keuangan. 


\section{SULTANIST: Jurnal Manajemen dan Keuangan, Vol 9 (2), Desember 2021}

3.Penyajian secara wajar (representation faithfulness)

Menggaambarkan keadaaan secara wajar dan lengkap, menunjukan hubungan antara data akuntansi dan peristiwaa-peristiwa yang sebenarnya digambarkan oleh data tersebut.

c. Dapat dibandingkan

Informasi yang termuat dalam laporan keuangan akan lebih bermanfaat apabila dapat dibandingkan dengan laporan keuangan periode sebelumnya atau laporan kauangan entitas pelaporan lain pada umumnya. Perbandingan dapat dilakukan secara internal dan eksternal. Perbandingan secara internal dilakukan apabila suatu entitas menerapkan kebijakan akuntansi yang sama dari tahun ketahun. Perbandingan secara eksternal dilakukan apabila entitas yang dibandingkan menerapkan kebijakan akuntansi yang sama.

d. Dapat dipahami.

Informasi dikatakan bermanfaat apabila dapat dengan mudah dipahami oleh pihak pengguna dan dinyakatakan dalam bentuk istilah yang disesuaikan dengan batas penggunaan. Pengguna diasumsikan memiliki pengetahuan yang memadai atas kegiatan dan lingkungan operasi entitas pelaporan, serta adanya kemauan pengguna untuk mempelajari informasi yang dimaksud.

\section{Tingkat Pendidikan}

Secara bahasa pendidikan adalah proses pengubahan sikap dan tata laku seseorang atau kelompok orang dalam usaha mendewasakan manusia melalui upaya pengajaran dan pelatihan. Menurut Malaya S.P Hasibuan mengatakan pendidikan meningkatkan keahlian teoritis, konseptual, dan moral karyawan. Sedangkan pengertian pendidikan menurut Soekidjo Notoatmodjo adalah suatu proses pengembangan kemampuan kearah yang diinginkan organisasi yang bersangkutan.

Menurut Sutrisno R. Pardoen (1992) mengemukakan bahwa salah satu bentuk human capital adalah pendidikan.Melalui pendidikan kualitas seseorang dapat ditingkatkan dalam berbagai aspek. Orang yang berpendidikan akan lebih rasional dalam berfikir dan bertindak serta memahami tugas dan tanggung jawab yang dibebankan kepadanya sehingga dapat melaksanakan tugas dan tanggung jawab tersebut dengan baik. Pendidikan terdiri dari dua yaitu pendidikan formal dan nonformal. Pendidikan formal berkaitan erat dengan segala sesuatu yang bertalian dengan perkembangan manusia mulai perkembangan fisik, kesehatan, keterampilan, pikiran, perasaan, kemauan, sosial, sampai kepada perkembangan iman. Tingkat pendidikan atau sering disebut dengan jenjang pendidikan adalah tahapan pendidikan yang ditetapkan berdasarkan tingkat perkembangan peserta didik, tujuan yang akan dicapai dan kemampuan yang dikembangkan.

Tingkat pendidikan seorang pegawai menunjukkan tingkat pengetahuan dan pemahamannya untuk menjalankan tugastugas yang dihadapi secara efisien. Pengetahuan dan pemahaman pegawai akan pelaksanaan kerja sangat menentukan dalam usaha mencapai hasil-hasil kerja yang telah ditetapkan. Dengan pendidikan formal yang memadai pegawai bagian keuangan akan lebih mudah mengerti dan memahami pekerjaan yang harus dilakukan. Maka semakin tinggi tingkat pendidikan seorang pegawai dan dengan latar belakang pendidikan akuntansi akan sangat membantu dalam membuat laporan keuangan. 


\section{SULTANIST: Jurnal Manajemen dan Keuangan, Vol 9 (2), Desember 2021}

\section{Pengalaman Kerja}

Pengalaman kerja menandakan seseorang pernah bekerja dan lamanya bekerja dalam bidang pekerjaan yang dilakukannya atau dalam jabatan pekerjaan yang pernah didudukinya. Pengalaman pegawai/karyawan dalam bekerja akan memberikan kemampuan bagi pegawai/karyawan tersebut terutama kemampuan dalam bekerja akan memberikan kemampuan dalam menjabarkan tugas pokok. Menurut Foster (2001: 40) menyatakan bahwa: "Pengalaman kerja adalah sebagai suatu ukuran tentang lama waktu atau masa kerjanya yang telah ditempuh seseorang dalam memahami tugas-tugas suatu pekerjaan dan telah melaksanakannya dengan baik.

Kemampuan seseorang tidak hanya diukur dari pendidikannya tetapi pengalaman kerja turut memberikan kontribusi yang cukup besar terhadap kemampuan seseorang dalam menangani pekerjaanya. Khususnya untuk pekerjaan yang rumit dan membutuhkan keahlian khusus.Dengan pengalaman yang dimiliki oleh pihak internal akan sangat membantu dalam menghasilkan kualitas penyajian laporan keuangan.

Pengalaman dan pendidikan sering digunakan secara bersamaan, karena

kombinasi antara pengalaman dan pendidikan dapat menciptakan kemampuan tersendiri dalam melaksanakan tugas-tugas perusahaan. Orang yang berpengalaman telah mempraktekkan teori yang pernah diperoleh dari belajar dan pendidikan. Dengan demikian perpaduan antara pengalaman dan pendidikan akan lebih meningkatkan mutu pekerjaan atau tugastugas dalam aktivitasnya. Pengalaman merupakan cara pembelajaran yang baik bagi pihak internal untuk menjadikan pegawainya kaya akan kualitas penyajian laporan keuangan. Semakin tinggi pengalaman yang dimiliki seorang pihak internal, maka semakin mampu dan mahir pegawai itu mengusai tugasnya sendiri maupun aktivitas yang dikerjakannya. Pengalaman juga membentuk pihak internal mampu menghadapi dan menyelesaikan hambatan maupun persoalan dalam pelaksanaan tugasnya. Selain pengetahuan dan keahlian, dan pengalaman pihak internal memberi kontribusi yang relevan dalam meningkatkan kompetensi laporan keuangan.

\section{Pelatihan}

Pada hakekatnya kegiatan pelatihan atau training perlu dilaksanakan oleh suatu perusahaan atau organisasi dengan tujuan meningkatkan keterampilan dan pengetahuan karyawan. Banyak ahli berpendapat tentang arti, tujuan dan manfaat pelatihan. Namun dari berbagai pendapat tersebut pada prinsipnya tidak jauh berbeda. Sikula dalam Sumantri (2000:2) mengartikan pelatihan sebagai: "proses pendidikan jangka pendek yang menggunakan cara dan prosedur yang sistematis dan terorganisir. Para peserta pelatihan akan mempelajari pengetahuan dan keterampilan yang sifatnya praktis untuk tujuan tertentu". Pelatihan adalah suatu proses membantu orang lain dalam memperoleh skill dan pengetahuan (Anwar P Mangkunegara, 2007 : 5). Sedangkan Michael J. Jucius dalam Anwar P Mangkunegara (2007 : 2) menjelaskan istilah latihan untuk menunjukkan setiap proses untuk mengembangkan bakat, keterampilan dan kemampuan pegawai guna menyelesaikan pekerjaan-pekerjaan tertentu. Pelatihan mengandung makna yang lebih khusus (spesifik), dan berhubungan dengan pekerjaan/tugas yang dilakukan seseorang. 
Sedangkan yang dimaksudkan praktis adalah, bahwa responden yang sudah dilatihkan dapat diaplikasikan dengan segera sehingga harus bersifat praktis, (Fandi Tjiptono, dkk, 1996). Definisi pelatihan menurut Center for Development Management and Productivity adalah belajar untuk mengubah tingkah laku orang dalam melaksanakan pekerjaan mereka. Pelatihan pada dasarnya adalah suatu proses memberikan bantuan bagi para karyawan atau pekerja untuk menguasai keterampilan khusus atau membantu untuk memperbaiki kekurangan dalam melaksanakan pekerjaan mereka. Perbedaan yang nyata dengan pendidikan, diketahui bahwa pendidikan pada umumnya bersifat filosofis, teoritis, bersifat umum, dan memiliki rentangan waktu belajar yang relatif lama dibandingkan dengan suatu pelatihan. Sedangkan yang dimaksudkan dengan pembelajaran, mengandung makna adanya suatu proses belajar yang melekat terhadap diri seseorang. Pembelajaran terjadi karena adanya orang yang belajar dan sumber belajar yang tersedia. Dalam arti pembelajaran merupakan kondisi seseorang atau kelompok yang melakukan proses belajar. Berdasarkan pengertian di atas maka dapat disimpulkan bahwa yang dimaksud pelatihan dalam hal ini adalah proses pendidikan yang di dalamnya ada proses pembelajaran dilaksanakan dalam jangka pendek, bertujuan untuk meningkatkan pengetahuan, sikap dan keterampilan, sehingga mampu meningkatkan kompetensi individu untuk menghadapi pekerjaan di dalam organisasi sehingga tujuan organisasi dapat tercapai. Dengan demikian dapat simpulkan bahwa "pelatihan sebagai suatu kegiatan untuk meningkatkan kinerja saat ini dan kinerja mendatang".

\section{METODE}

\section{Populasi dan Sampel}

Populasi dalam penelitian ini adalah seluruh pengurus Bumdes dan Perangkat Desa Sekecamatan Pasir Penyu Kabupaten Indragiri Hulu. Kemudian seluruh populasi ini dijadikan sampel. Sehinggga sampel dalam penelitian ini berjumlah 40 responden

\section{Jenis dan Sumber Data}

Jenis data yang dikumpulkan adalah data primer dan data sekunder yang bersifat kualitatif dan kuantitatif, sedangkan data yang ditinjau dari sumbernya adalah :

Data primer merupakan data yang diperoleh langsung dari pengurus Bumdes dan Perangkat Desa.

Data sekunder yaitu mengambil laporan keuangan dan dokumen pendukung lainnya dari tiap Bumdes yang ada diKecamatan Pasir Penyu

\section{Teknik Pengumpulan Data}

Data-data yang digunakan dalam penelitian ini adalah data primer dan data sekunder yang berhubungan dengan variabel yang diteliti yaitu :

Data primer yaitu pengambilan data dilakukan secara langsung yang berasal dari sumbernya dengan melakukan wawancara dan observasi langsung di lapangan dengan membagikan kuisioner kepada pengurus Bumdes dan Perangkat Desa..Data sekunder yaitu pengambilan data yang dilakukan dengan meminta data Laporan Keuangan dan dokumen pengdukung lainnya.

\section{Variabel Penelitian}

Ada 2 variabel yang digunakan dalam penelitian ini yaitu variable penyebab (Independent Variabel) yang dilambangkan dengan $\mathrm{X}$ adalah sebagai berikut: Tingkat Pendidikan (X1), Pengalaman Kerja (X2), 
Pelatihan (X3). Dan variabel akibat (Dependent Variabel) yang dilambangkan dengan $Y$ adalah Kualitas Laporan Keuangan.

\section{Teknik Analisa Data}

Uji Instrumen; Uji Validitas; Uji Reliabilitas. dan Uji Asumsi Klasik; Uji Normalitas; Linieritas.

\section{Uji Instrumen}

Sebelum melakukan pengolahan data, terlebih dahulu harus menguji kuesioner yang akan digunakan, apakah instrumen penelitian yang berupa kuesioner sudah valid dan reliabel ataukah belum.

\section{Uji Validitas}

Azwar dalam jurnalnya Zulkifli, menyatakan bahwa validitas berasal dari kata validity yang mempunyai arti sejauh mana ketepatan dan kecermatan suatu instrumen pengukur (tes) dalam melakukan fungsi ukurnya. Suatu tes dikatakan memiliki validitas yang tinggi apabila alat tersebut menjalankan fungsi ukur secara tepat atau memberikan hasil ukur yang sesuai dengan maksud dilakukannya pengukuran tersebut. artinya hasil ukur dari pengukuran tersebut merupakan besaran yang mencerminkan secara tepat fakta atau keadaan sesungguhnya dari apa yang diukur. Untuk menguji validitas menggunakan kolom corrected item total correlation. Jika nilai item pernyataan pada kolom tersebut lebih besar dari 0,3 maka item pernyataan valid, dan jika lebih kecil dai 0,3 maka item pernyataan tersebut tidak valid.

\section{Uji Reliabilitas}

Reliabilitas berasal dari kata reliability yang berarti sejauh mana hasil suatu pengukuran memiliki keterpercayaan, keterandalan, kejegan, konsistensi, kestabilan yang dapat dipercaya. Hasil ukur dapat dipercaya apabila dalam beberapa kali pengukuran terhadap kelompok subjek yang sama diperoleh hasil yang relatif sama. Untuk menguji reliabilitas kuesioner, gunakan kolom cronbanch's alpha. Jika nilainya lebih besar dari 0,7 maka kuesioner reliabel, dan jika lebih kecil dari 0,7 maka kuesioner tidak reliabel.

\section{Analisis Regresi Linier Berganda}

Analisis Regresi Linear Berganda digunakan untuk mengukur pengaruh antara variabel bebas (Tingkat Pendidikan, Pengalaman Kerja, dan Pelatihan) terhadap variabel terikat (Kualitas Laporan Keuangan)

$$
Y=a+b 1 X 1+b 2 X 2+b 3 X 3+e
$$

Keterangan:

$\mathrm{Y} \quad=$ Kualitas Laporan Keuangan

$\mathrm{a} \quad=$ Konstanta

b1 = Koef Regresi Tingkat Pendidikan

$\mathrm{X} 1=$ Tingkat Pendidikan

b2 = Koef Regresi Pengalaman Kerja

$\mathrm{X} 2=$ Pengalaman Kerja

b3 = Koefisien Regresi Pelatihan

$\mathrm{X} 3$ = Pelatihan

\section{HASIL DAN PEMBAHASAN}

\section{Uji Instrumen}

\section{a. Uji Validitas}

Sebelum dilakukan pengujian hipotesis juga harus dilakukan pengujian validitas. Validitas adalah sebuah pengujian yang 
bertujuan untuk mengetahui keakuratan dari item-item yang digunakan untuk mengukur kebenaran sebuah variabel. Jika sebuah item tidak valid maka akan menimbulkan standar error yang tinggi sehingga akan mengurangi tingkat keakuratan hasil yang ditemukan dalam sebuah penelitian. Dari pengolahan data dengan program SPSS diperoleh hasil uji validitas terhadap pernyataan-pernyataan (item) (X dan $\mathrm{Y}$ ) sebagai berikut : Tingkat Pendidikan (X1), Pengalaman Kerja (X2), dan Pelatihan (X3) dari 6 pernyataan seluruhnya valid dan tidak terdapat pertanyaan yang tidak valid sebab nilai rhitung $>$ rtabel pada $\alpha=0,05$ dimana rtabel $=0,312$ dan dapat dilihat pada tabel di bawah ini:

Tabel 2 Uji Validitas Variabel Tingkat Pendidikan (X1)

\begin{tabular}{|c|c|c|c|}
\hline Pernyataan & r Hitung & r Tabel & Kesimpulan \\
\hline PK1 & 0.623 & 0.312 & Valid \\
\hline PK2 & 0.612 & 0.312 & Valid \\
\hline PK3 & 0.627 & 0.312 & Valid \\
\hline PK4 & 0.455 & 0.312 & Valid \\
\hline PK5 & 0.687 & 0.312 & Valid \\
\hline PK6 & 0.499 & 0.312 & Valid \\
\hline
\end{tabular}

Sumber : Olahan Data SPSS

Dari table 2 setelah dilakukan lagi uji validitas terhadap item pernyataan variabel Tingkat Pendidikan (X1) yang digunakan dalam penelitian ini dan terbukti 6 item pernyataan yang digunakan dalam penelitian ini dinyatakan valid. Seluruh nilai Corelation Item (rhitung) untuk seluruh pertanyaan lebih besar dari nilai Corelation tabel ( $\mathrm{r}$ tabel) pada $n=40, \alpha=0,05$ yaitu 0,312 , sehingga dapat dilanjutkan dalam penelitian.
Tabel 3 Uji Validitas Variabel Pengalaman Kerja (X2)

\begin{tabular}{|l|l|l|l|}
\hline Pernyataan & $r$ Hitung & $r$ Tabel & Kesimpulan \\
\hline PK1 & 0.707 & 0.312 & Valid \\
\hline PK2 & 0.631 & 0.312 & Valid \\
\hline PK3 & 0.334 & 0.312 & Valid \\
\hline PK4 & 0.587 & 0.312 & Valid \\
\hline PK5 & 0.684 & 0.312 & Valid \\
\hline PK6 & 0.584 & 0.312 & Valid \\
\hline
\end{tabular}

Sumber : Olahan Data SPSS

Dari table 3 setelah dilakukan lagi uji validitas terhadap item pernyataan variabel Pengalaman Kerja (X2) yang digunakan dalam penelitian ini dan terbukti 6 item pernyataan yang digunakan dalam penelitian ini dinyatakan valid. Seluruh nilai Corelation Item (rhitung) untuk seluruh pertanyaan lebih besar dari nilai Corelation tabel ( $\mathrm{r}$ tabel) pada $n=40, \alpha=0,05$ yaitu 0,312 , sehingga dapat dilanjutkan dalam penelitian.

Tabel 4 Uji Validitas Variabel Pelatihan (X3)

\begin{tabular}{|c|c|c|c|}
\hline Pernyataan & r Hitung & $r$ Tabel & Kesimpulan \\
\hline P1 & 0.569 & 0.312 & Valid \\
\hline P2 & 0.514 & 0.312 & Valid \\
\hline P3 & 0.583 & 0.312 & Valid \\
\hline P4 & 0.528 & 0.312 & Valid \\
\hline P5 & 0.753 & 0.312 & Valid \\
\hline P6 & 0.600 & 0.312 & Valid \\
\hline
\end{tabular}

Sumber : Olahan Data SPSS

Dari tabel 4 setelah dilakukan lagi uji validitas terhadap item pernyataan variabel Pelatihan (X3) yang digunakan dalam penelitian ini dan terbukti 6 item pernyataan yang digunakan dalam penelitian ini dinyatakan valid. Seluruh nilai Corelation Item (rhitung) untuk seluruh pertanyaan lebih besar dari nilai Corelation tabel ( $\mathrm{r}$ tabel) 
pada $\mathrm{n}=40, \alpha=0,05$ yaitu 0,312 , sehingga dapat dilanjutkan dalam penelitian.

Untuk pengujian validitas variabel Keputusan Pembelian (Y) secara rinci dapat dilihat pada tabel di bawah ini:

Tabel 4 Uji Validitas Variabel Kualitas Laporan Keuangan (Y)

\begin{tabular}{|c|c|c|c|}
\hline Pernyataan & r Hitung & r Tabel & Kesimpulan \\
\hline KLK1 & 0.682 & 0.312 & Valid \\
\hline KLK2 & 0.658 & 0.312 & Valid \\
\hline KLK3 & 0.665 & 0.312 & Valid \\
\hline KLK4 & 0.484 & 0.312 & Valid \\
\hline KLK5 & 0.585 & 0.312 & Valid \\
\hline KLK6 & 0.437 & 0.312 & Valid \\
\hline
\end{tabular}

Sumber : Olahan Data SPSS

Dari tabel 4 setelah dilakukan lagi uji validitas terhadap item pernyataan variabel Kualitas Laporan Keuagan (Y) yang digunakan dalam penelitian ini dan terbukti 6 item pernyataan yang digunakan dalam penelitian ini dinyatakan valid. Seluruh nilai Corelation Item (rhitung) untuk seluruh pertanyaan lebih besar dari nilai Corelation tabel (rtabel) pada $n=40, \alpha=0,05$ yaitu 0,312 , sehingga dapat dilanjutkan dalam penelitian.

\section{Uji Reliabilitas}

Uji reliabilitas bertujuan untuk mengetahui sejauh mana hasil pengukuran tetap konsisten, jika dilakukan pengukuran kedua kali atau lebih. Reliabilitas adalah indeks yang menunjukkan sejauh mana alat pengukur dapat dipercaya dan handal. Dalam penelitian ini, pengujian reliabilitas dilakukan dengan menggunakan metode cronbach's alpha.

Suatu instrument dikatakan reliabel apabila memiliki nilai cronbach's alpha lebih dari 0,60. Hasil uji reliabilitas dalam penelitian disajikan pada tabel 5 berikut :

\section{Tabel 5 Hasil Uji Reliabilitas}

\begin{tabular}{|l|c|c|}
\hline \multicolumn{1}{|c|}{ Variabel } & Cronbach's Alpha & Keterangan \\
\hline Tingkat Pendidikan (X1) & 0,616 & Reliabel \\
\hline Pengalaman Kerja (X2) & 0,618 & Reliabel \\
\hline Pelatihan (X3) & 0,620 & Reliabel \\
\hline Kualitas Laporan & 0,612 & Reliabel \\
Keuagan (Y) & & \\
\hline \multicolumn{2}{|l}{ Sumber : Data Olahan SPSS } \\
\hline
\end{tabular}

Dari table 5 terlihat hasil pengujian reliabilitas data untuk semua variabel yang digunakan dalam penelitian ini. Dimana semua variabel memiliki nilai cronbach's Alpha di atas 0,60. Kualitas Laporan Keuangan (Y) memiliki Cronbach's Alpha sebesar 0,612, variabel Tingkat Pendidikan (X1) memiliki nilai Cronbach's Alpha sebesar 0,616, variabel Pengalaman Kerja(X2) memiliki nilai Cronbach's Alpha sebesar 0,618, variabel Pelatihan(X3) memiliki nilai Cronbach's Alpha sebesar 0,620. Ini menunjukkan bahwa instrument yang digunakan untuk semua variabel tersebut adalah andal dan reliabel.

\section{Uji Asumsi Klasik}

\section{a. Uji Normalitas}

Hasil Uji normalitas merupakan persyaratan penting yang harus terpenuhi dalam analisis jalur. Bila data yang dianalisis tidak di berdistribusi normal, maka analisis regresi tidak dapat terpenuhi. Uji normalitas berpedoman pada uji Kolmogorov yaitu :

- Jika nilai signifikansi < 0,05 (taraf kepercayaan $95 \%$ ) distribusi adalah tidak normal.

- Jika nilai signifikansi > 0,05 (taraf kepercayaan $95 \%$ ) distribusi adalah normal

Hasil perhitungan uji normalitas dapat di lihat pada tabel 6 di bawah ini 
Table 6. Hasil Uji Normalitas Data Kolmograv-Smirnov (K-S)

\begin{tabular}{|ll|r|}
\hline & & \multicolumn{2}{|c|}{$\begin{array}{l}\text { Unstandardized } \\
\text { Residual }\end{array}$} \\
\hline N & & 40 \\
\hline Normal Parameters & Mean & 0.0000000 \\
& Std. & 1.34439664 \\
& Deviation & 0.126 \\
& Most Extreme Differences Absolute & 0.126 \\
& Positive & -0.111 \\
& Negative & 0.126 \\
\hline Test Statistic & & 0.109 \\
\hline Asymp. Sig. (2-tailed) & &
\end{tabular}

Sumber : Olahan Data SPSS

Dari tabel 6 dilihat tingkat sig adalah 0,109 nilainya lebih besar dari tingkat signifikan yang digunakan pada penelitian ini $(\alpha=0,05)$. Dengan demikian dapat disimpulkan bahwa semua variabel tersebut berdistribusi normal.

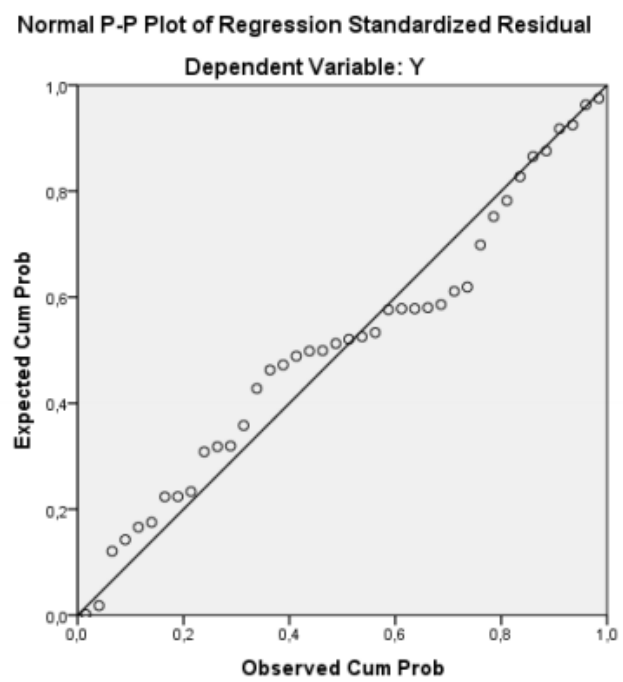

\section{b. Uji Heterokedastisitas}

Untuk menguji ada tidaknya heteroskedastisitas dapat ditentukan dengan melihat grafik plot (scatterplot) antara nilai prediksi variabel terikat (ZPRED) dengan residual (SRESID). Dasar pengambilan keputusannya adalah jika ada pola tertentu seperti titik-titik yang ada membentuk pola tertentu yang teratur (bergelombang, melebar, kemudian menyempit) maka diindikasikan telah terjadi heteroskedastisitas. Jika tidak ada pola yang yang jelas, serta titik-titik menyebar diatas dan dibawah angka nol pada sumbu Y, maka tidak terjadi heteroskedastisitas (Ghozali,2013:139).

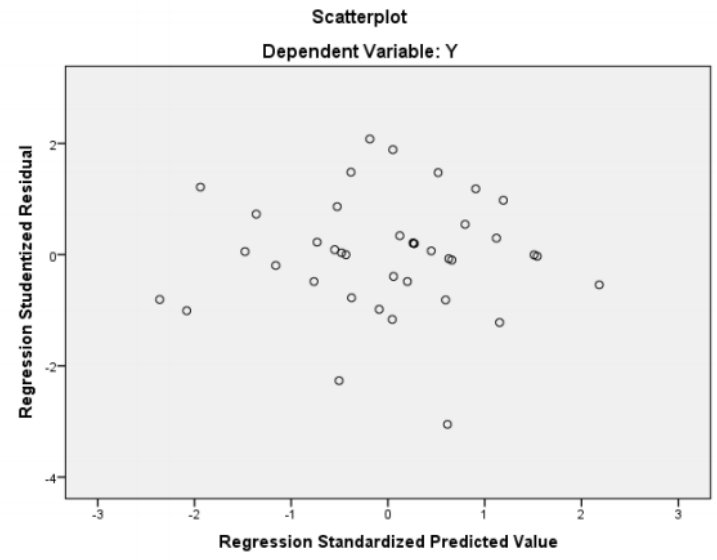

Dari grafik scatterplot pada gambar di atas dapat dilihat bahwa titik-titik menyebar secara acak, serta tersebar baik diatas maupun dibawah angka nol pada sumbu Y. Hal ini dapat disimpulkan bahwa tidak terjadi heterokedastisitas pada model regresi.

\section{c. Uji Multikolinearitas}

Uji Multikolinearitas berguna untuk menghindari agar di antara variabel independen tidak berkorelasi sesamanya. Model regresi yang baik seharusnya tidak terjadi korelasi di antara variabel bebas. Jika variabel bebas saling berkorelasi, maka variabel-variabel tersebut tidak orthogonal. Variabel orthogonal adalah variabel bebas yang nilai korelasi antar sesama variabel bebes sama dengan 0 (nol).

Untuk mengetahui ada tidaknya multikolinearitas dalam model regregi dapat dilihat melalui VIF (varians Inflation Factor). Bila angka tolerance $>0,10$ atau nilai VIF $<10$, maka tidak terjadi gejala multikolinearitas.

Hasil uji multikolinearitas dapat dilihat pada tabel 7 berikut ini : 
Tabel 7. Hasil Uji Multikolinieritas

\begin{tabular}{|l|c|c|c|}
\hline \multirow{2}{*}{ Model } & \multicolumn{3}{c|}{ Collinearity Statistics } \\
\cline { 2 - 4 } & Tolerance & VIF & Keterangan \\
\hline Tingkat Pendidikan (X1) & 0.967 & 1.034 & $\begin{array}{r}\text { Tidak terdapat } \\
\text { Multikolinieritas }\end{array}$ \\
\hline Pengalaman Kerja(X2) & 0.917 & 1.090 & $\begin{array}{r}\text { Tidak terdapat } \\
\text { Multikolinieritas }\end{array}$ \\
\hline Pelatihan(X3) & 0.935 & 1.069 & $\begin{array}{c}\text { Tidak terdapat } \\
\text { Multikolinieritas }\end{array}$ \\
\hline \\
Sumber : Data Olahan SPSS
\end{tabular}

Berdasarkan hasil analisis regresi berganda pada tabel $7 \mathrm{di}$ atas, terlihat bahwa variabel bebas dalam penelitian ini yaitu Tingkat Pendidikan, Pengalaman Kerja, dan Pelatihan tidak ada yang kecil dari 0,1 dan nilai VIF tidak ada yang besar dari 10. Nilai tolerance Tingkat Pendidikan (X1) adalah 0, 967, Nilai toleransi Pengalaman Kerja(X2) adalah 0,917, Nilai toleransi Pelatihan(X3) adalah 0,935 dan hal yang sama juga terjadi pada nilai VIF, dimana nilai VIF Tingkat Pendidikan (X1) adalah 1,034, nilai VIF Pengalaman Kerja(X2) adalah 1,090 serta nilai VIF Pelatihan(X3) adalah 1,069. Dengan demikian di antara variabel independen dinyatakan bebas dari multikolinearitas

\section{Hasil Analisis Regresi Lknear Berganda}

Tabel 8. Hasil Analisis Regresi Linier Berganda Coefficients*

\begin{tabular}{|c|c|c|c|c|c|}
\hline \multirow[b]{2}{*}{ Model } & \multicolumn{2}{|c|}{$\begin{array}{c}\text { Unstandardized } \\
\text { Coefficients }\end{array}$} & \multirow{2}{*}{ 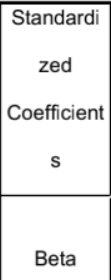 } & \multirow[b]{2}{*}{$t$} & \multirow[b]{2}{*}{ Sig. } \\
\hline & B & $\begin{array}{l}\text { Std. } \\
\text { Error }\end{array}$ & & & \\
\hline 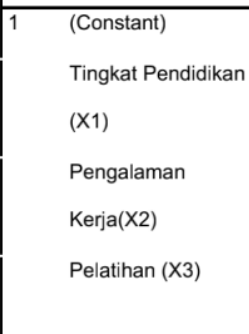 & $\begin{array}{l}, 345 \\
, 367\end{array}$ & ,126 &, 299 & \begin{tabular}{r|}
, 056 \\
2,91 \\
8 \\
2,16 \\
5 \\
2,57 \\
4
\end{tabular} & $\begin{array}{l}, 955 \\
, 006 \\
, 037 \\
, 014\end{array}$ \\
\hline
\end{tabular}

Berdasarkan tabel 8, maka dapat dibuat dalam bentuk persamaan regresi sebagai berikut:

$\mathrm{Y}=\alpha+\beta 1 \mathrm{X} 1+\beta 2 \mathrm{X} 2+\beta 3 \mathrm{X} 3+\mathrm{e}$

Keterangan: $\mathrm{Y}=$ Kualitas Laporan

Keuangan

$\alpha=$ konstanta

$\beta=$ koefisien regresi

$\mathrm{X} 1=$ Variabel Tingkat Pendidikan

$\mathrm{X} 2=$ Variabel Pengalaman Kerja

X3 = Variabel Pelatihan

$\mathrm{e}=$ error

Berdasarkan tabel 8 yang didapat dari hasil analisi menggunakan spss versi 23, maka didapat persamaan regresi linear bergandanya adalah sebagai berikut :

$$
\mathrm{Y}=0.345+0.367 \mathrm{X}_{1}+0.294 \mathrm{X}_{2}+
$$

$0.327 \mathrm{X}_{3}+\mathrm{e}$

Persamaan regresi tersebut dapat dijeleskan sebagai berikut:

1. Nilai konstanta (a) sebesar 0.345 artinya adalah apabila variabel independen diasumsikan nol (0), maka Kualitas Laporan Keuangan sebesar 0.345

2. Nilai koefisien X1 sebesar 0.367 menunjukkan bahwa variabel Tingkat Pendidikan berpengaruh positif terhadap Kualitas Laporan Keuangan, atau dengan kata lain jika ditingkatkan nilai Tingkat Pendidikan sebesar $1 \%$ maka akan menigkat Kualitas Laporan Keuangan sebesar 0.367

3. Nilai koefisien X2 sebesar 0.294 menunjukkan bahwa variabel Pengalaman Kerja berpengaruh positif terhadap Kualitas Laporan Keuangan, atau dengan kata lain jika ditingkatkan nilai Pengalaman Kerjasebesar $1 \%$ maka akan menigkat Kualitas Laporan Keuangan sebesar 0.294

4. Nilai koefisien X3 sebesar 0.327 menunjukkan bahwa variabel Pelatihanberpengaruh positif terhadap Kualitas Laporan Keuangan, atau 
dengan kata lain jika ditingkatkan nilai Pelatihan sebesar $1 \%$ maka akan menigkat Kualitas Laporan Keuangan sebesar 0.327

\section{Koefisien Determinasi $\left(\mathbf{R}^{2}\right)$}

Berdasarkan hasil perhitungan regresi linear berganda dengan menggunakan bantuan program statistik IBM SPSS versi 23.0 maka diperoleh koefisien determinasi seperti yang terdapat pada tabel berikut.

Tabel 9. Model Summary Perhitungan Regresi

\begin{tabular}{|c|c|c|c|c|}
\hline Model & $\mathrm{R}$ & $\mathrm{R}$ & Square \\
Square & & $\begin{array}{c}\text { Stjusted } \mathrm{R} \\
\text { Estimate }\end{array}$ \\
\hline 1 & 0.608 & 0.370 & 0.318 & 1.399 \\
\hline \multicolumn{3}{|c|}{ Sumber : Data Olahan IBM SPSS Versi 23.0} \\
\hline
\end{tabular}

Berdasarkan 210aria 9 juga dapat terlihat koefisien determinasi $\left(\mathrm{R}^{2}\right)$. Dari 210aria model summary tersebut dapat diketahui nilai Adjusted R Square adalah 0.318. Jadi, sumbangan pengaruh dari 210ariable independent yaitu 31,8\%, sedangkan sisanya sebesar $68,2 \%$ dipengaruhi oleh 210ariable lain yang tidak diteliti dalam penelitian ini.

\section{Uji Parsial}

$$
\begin{aligned}
\text { Df } & =\alpha / 2 ; \mathrm{n}-\mathrm{k} \\
& =0,05 / 2 ; 40-3 \\
& =0,025 ; 37 \\
& =2,026
\end{aligned}
$$

Tabel 10. Hasil Regresi Parsial Hipotesis Pertama

\begin{tabular}{|c|c|c|c|c|}
\hline Variabel Independen & thitung & tabel & Sig & Keterangan \\
\hline Tingkat Pendidikan & 2,918 & 2,026 & 0,006 & Berpengaruh \\
\hline
\end{tabular}

Sumber: data olahan SPSS.

Untuk variable Tingkat Pendidikan (X1), diperoleh $t_{\text {hitung }} 2,918>t_{\text {tabel }} 2,026$ atau Sig $0,006<\alpha 0,05$. Berdasarkan kriteria pengujian data dapat diketahui bahwa $\mathrm{H}_{0}$ ditolak dan $\mathrm{H}_{\mathrm{a}}$ diterima, artinya Tingkat Pendidikan secara parsial berpengaruh terhadap Kualitas Laporan Keuangan.

Tabel 11. Hasil Regresi Parsial Hipotesis Kedua

\begin{tabular}{|c|c|c|c|c|}
\hline Variabel Independen & thitung & tabel & Sig & Keterangan \\
\hline Pengalaman Kerja & 2,165 & 2,026 & 0,037 & Berpengaruh \\
\hline
\end{tabular}

Sumber: data olahan SPSS

Untuk variable Pengalaman Kerja (X2), diperoleh $t_{\text {hitung }} 2,165>t_{\text {tabel }} 2,026$ atau Sig $0,037<\alpha$ 0,05. Berdasarkan kriteria pengujian data dapat diketahui bahwa $\mathrm{H}_{0}$ ditolak dan $\mathrm{H}_{\mathrm{a}}$ diterima, artinya Pengalaman Kerja secara parsial berpengaruh terhadap Kualitas Laporan Keuangan.

Tabel 12. Hasil Regresi Parsial Hipotesis Ketiga

\begin{tabular}{|c|c|c|c|c|}
\hline Variabel Independen & thitung & tabel & Sig & Keterangan \\
\hline Pelatihan & 2,574 & 2,026 & 0,014 & Berpengaruh \\
\hline
\end{tabular}

Sumber: data olahan SPSS

Untuk variable Pelatihan (X3), diperoleh $t_{\text {hitung }} 2,574>t_{\text {tabel }} 2,026$ atau Sig $0,014<\alpha$ 0,05. Berdasarkan kriteria pengujian data dapat diketahui bahwa $\mathrm{H}_{0}$ ditolak dan $\mathrm{H}_{\mathrm{a}}$ diterima, artinya Pelatihan secara parsial berpengaruh terhadap Kualitas Laporan Keuangan.

\section{UJI ANOVA}

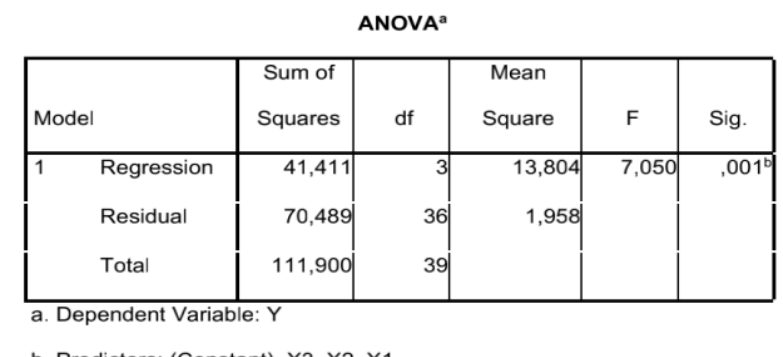

Dari tabel hasil perhitungan di atas, dapat diketahui bahwa $\mathrm{F}$ hitung sebesar 7,050 dan $\mathrm{F}$ tabel dengan taraf signifikan $5 \%$ yaitu 2,87 
Dari table Anova dapat dilihat $\mathrm{F}$ hitung yaitu 7,050 sedangkan $\mathrm{F}$ table yaitu 2,87. Maka dapat ditarik kesimpulan bahwa $\mathrm{F}$ hitung $>\mathrm{F}$ table maka Ho ditolak dan $\mathrm{Ha}$ diterima. Artinya variable Tingkat Pendidikan, Pengalaman Kerja, dan Pelatihan secara bersama-sama memiliki pengaruh signifikan terhadap Kualitas Laporan Keuangan Bumdes Sekecamatan Pasir Penyu

\section{Koefisien Korelasi (R)}

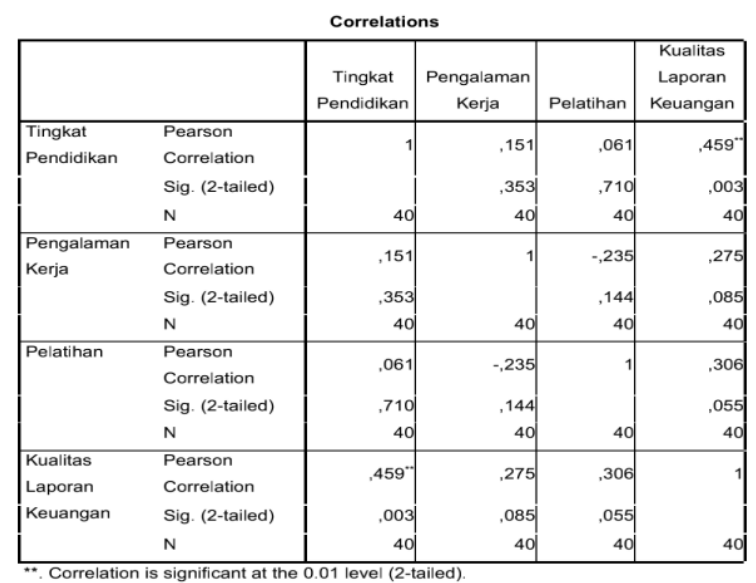

\section{KESIMPULAN DAN SARAN}

\section{Kesimpulan}

Berdasarkan hasil analisis data yang telah dilakukan dalam penelitian ini, maka diperoleh simpulan sebagai berikut :

1. Tingkat Pendidikan secara parsial berpengaruh terhadap Kualitas Laporan Keuangan Bumdes SeKecamaran Pasir Penyu. Sesuai dengan penelitian terdahulu yang dilakukan oleh (Muzahid : 2014) dimana Secara parsial tingkat Pendidikan berpengaruh positif terhadap kualitas laporan keuangan satuan kerja perangkat daerah (SKPD) Pemerintah Kabupaten Aceh Utara.

2. Pengalaman Kerja secara parsial berpengaruh terhadap Kualitas Laporan Keuangan Bumdes SeKecamaran Pasir Penyu. Sesuai dengan penelitian terdahulu yang dilakukan oleh (Sukarini : 2019) dimana Variabel pengalaman kerja memiliki nilai thitung lebih besar dari ttabel, yaitu nilai signifikansi 0,000 yang lebih kecil 0,05, sehingga didapatkan hasil bahwa variabel pengalaman kerja berpengaruh positif dan signifikan terhadap kualitas laporan keuangan.

3. Pelatihan secara parsial berpengaruh terhadap Kualitas Laporan Keuangan Bumdes SeKecamaran Pasir Penyu. Sesuai dengan penelitian terdahulu yang dilakukan oleh (Wungow : 2016) pelatihan berpengaruh terhadap kualitas laporan keuangan pemerintah Kabupaten Minahasa Selatan, hal ini menunjukkan bahwa semakin banyak pelatihan yang diikuti pegawai sesuai dengan bidang kerjanya maka akan semakin terampil dan berkualitas pegawai tersebut

\section{Saran}

Berdasarkan hasil penelitian dan analisis data yang telah dilakukan, maka saran-saran yang dapat diberikan adalah:

1. Untuk peneliti selanjutnya bisa menambah jumlah sampel atau perluasan objek penelitian agar mendapatkan hasil yang lebih akurat dan sesuai dengan grand teori yang ada.

2. Untuk peneliti selanjutnya agar dapat menambah variable independen karena dalam penelitian ini sumbangan pengaruh dari variabel independen hanya $31,8 \%$, sedangkan sisanya sebesar 68,2\% dipengaruhi oleh variabel lain seperti variable sistem informasi akuntansi dan lainnya.

3. Untuk pengelola Bumdes, dengan adanya penelitian ini diharapkan dapat menambah wawasan terkait faktor yang 
mempengaruhi kualitas laporan BUMDes. Dengan diketahuinya faktor faktor apa saja yang mempengaruhi diharapkan kedepannya laporan keuangan BUMDes sudah sesuai dengan aturan yang berlaku

\section{DAFTAR PUSTAKA}

Bukit, R., \& Lubis, T. A. S. (2017). Pengaruh Pelatihan, Pemanfaatan SIPKD, Kompetensi Dan Pengendalian Intern Terhadap Kualitas Laporan Keuangan Pada SKPD Kabupaten Bireuen Dengan Gaya Kepemimpinan Sebagai Variabel Moderating.

Eka Putra, W. (2017). Analisis FaktorFaktor Yang Mempengaruhi Kualitas Laporan Keuangan Pemerintah Daerah (Studi Empiris Pada Pemerintah Kota Jambi) (Analysis of Factors Affecting Quality of Local Government Financial Statements (Empirical Study of the Jambi City Government. Jurnal Riset Akuntansi Terpadu, 10(2), 282-293.

Fitrawansah, F. (2015). Faktor-faktor yang Memengaruhi Kualitas Laporan Keuangan Pemerintah Daerah (Studi Empiris pada Pemerintah Daerah Kabupaten Sinjai) (Doctoral dissertation, Universitas Islam Negeri Alauddin Makassar).

Hasibuan, M. S., \& Hasibuan, H. M. S. (2016). Manajemen sumber daya manusia. Bumi Aksara.

Ikatan Akuntansi Indonesia. PSAK No. 1 Tentang Laporan Keuangan- edisi revisi 2015. Penerbit Dewan Standar Akuntansi Keuangan: PT. Raja Grafindo.

Ishak, P., \& Syam, F. (2020). Pengaruh Kompetensi Dan Penggunaan Teknologi Informasi Akuntansi Terhadap Kualitas Laporan Keuangan BUMDES. Journal of
Technopreneurship on Economics and Business Review, 1(2), 120-130.

Mahaputra, I. P. U. R., \& Putra, I. W. (2014). Analisis Faktor-Faktor yang Memengaruhi Kualitas Informasi Pelaporan Keuangan Pemerintah Daerah. E-Jurnal Akuntansi Universitas Udayana, 8(2), 230-244. Mahmudi. 2011. Akuntansi Sektor Publik.

Yogyakarta: Penerbit UII Press.

Mangkunegara, A. A. P. (2005). Evaluasi kinerja SDM. Tiga Serangkai.

Mardiasmo, D., \& MBA, A. (2009). Akuntansi sektor publik. Yogyakarta: Andi.

Mulia, R. A. (2019). Analisis Faktor-Faktor Yang Mempengaruhi Kualitas Laporan Keuangan Pemerintah Daerah (Studi Pada Pemerintah Kabupaten Pasaman Barat). Jurnal El-Riyasah, 9(1), 7-21.

Muzahid, M. (2014). Pengaruh tingkat pendidikan, kualitas pelatihan, dan lama pengalaman kerja pegawai terhadap kualitas laporan keuangan Satuan Kerja Perangkat Daerah (SKPD) di Kabupaten Aceh Utara. Jurnal Akuntansi (Media Riset Akuntansi \& Keuangan), 2(2), 179-196.

Nahartyo, E., \& Indriasari, D. (2008). Pengaruh Kapasitas Sumberdaya Manusia, Pemanfaatan Teknologi Informasi, Dan Pengendalian Intern Akuntansi Terhadap Nilai Informasi Pelaporan Keuangan Pemerintah Daerah (Studi Pada Pemerintah Kota Palembang dan Kabupaten Ogan Ilir).

Nugraheni, P., \& Subaweh, I. (2008). The Effect of Implementation of Government Accounting Standards on Quality of Financial Statements. Journal of Economics and Business, 13(1), 48-58.

Peraturan Menteri Desa, Pembangunan Daerah Tertinggal, Dan Transmigrasi Republik Indonesia Nomor 4 Tahun 2015 Tentang Pendirian, Pengurusan Dan 


\section{SULTANIST: Jurnal Manajemen dan Keuangan, Vol 9 (2), Desember 2021}

Pengelolaan, Dan Pembubaran Badan Usaha Milik Desa

Peraturan Pemerintah Republik Indonesia Nomor 71 Tahun 2010 Tentang Standar Akuntansi Pemerintahan

Pradono, F. C. (2015). Kualitas Laporan Keuangan Pemerintah Daerah: Faktor yang mempengaruhi dan Implikasi Kebijakan (Studi Pada SKPD Pemerintah Provinsi Jawa Tengah). Jurnal Bisnis Dan Ekonomi, 22(2).

Riyanita, A. G. (2020). Analisis Pengaruh Sistem Pengendalian Internal, Pelatihan Dan Pemanfaatan Teknologi Informasi Terhadap Kualitas Laporan Keuangan (Studi Empiris Pada Perangkat Desa Di Kabupaten Sleman) (Doctoral dissertation, Universitas Muhammadiyah Yogyakarta).

Sukarini, L., \& Dewi, P. E. D. M. (2019). Pengaruh tingkat pendidikan, pengalaman kerja, pelatihan, dan penggunaan teknologi informasi terhadap kualitas laporan keuangan BUMDes di Kecamatan Negara. JIMAT (Jurnal Ilmiah Mahasiswa Akuntansi)

Undiksha, 9(3).

Sukmaningrum, T., \& Harto, P. (2012). Analisis Faktor-Faktor yang Mempengaruhi Kualitas Informasi Laporan Keuangan Pemerintah Daerah (Studi Empiris pada Pemerintah Kabupaten dan Kota Semarang) (Doctoral dissertation, Fakultas Ekonomika dan Bisnis).

Titioka, B. M., Huliselan, M., Sanduan, A., Ralahallo, F. N., \& Siahainenia, A. J. (2020). Pengelolaan Keuangan BUMDES di Kabupaten Kepulauan Aru. Jurnal Pengabdian Masyarakat Jamak, 3(1), 197-216.

Undang-Undang Republik Indonesia Nomor 6 Tahun 2014 Tentang Desa

Wardani, R. N. (2014). Pengaruh Tingkat Pendidikan, Pengalaman Kerja, dan Pengendalian Internal Terhadap Kualitas Laporan Keuangan Pada
Kantor Kementerian Agama Kota Makassar. Skripsi. Fakultas Ekonomi Dan Bisnis Islam. Universitas UIN Alaudin Makassar.

Wati, K. D., Herawati, N. T., AK, S., \& SINARWATI, N. K. (2014). Pengaruh Kompetensi SDM, Penerapan SAP, dan Sistem Akuntansi Keuangan Daerah Terhadap Kualitas Laporan Keuangan Daerah. JIMAT (Jurnal Ilmiah Mahasiswa Akuntansi) Undiksha, 2(1).

Wibawa, K. A. S., SINARWATI, N. K., Yuniarta, G. A., \& AK, S. (2017). Faktor-Faktor Yang Berpengaruh Terhadap Kualitas Laporan Keuangan Pemerintah Daerah Pada Skpd Kabupaten Buleleng. JIMAT $8(2)$.

Wineh, S. (2021). Faktor Yang Mempengaruhi Kualitas Laporan Keuangan Dengan Sistem Pengendalian Intern Sebagai Variabel Moderasi (Studi Kasus Pada Organisasi Perangkat Daerah Kabupaten Merangin, Jambi). DINAMIKA: Jurnal Manajemen Akuntansi, Bisnis dan Kewirausahaan, 5(1), 63-84.

Winidyaningrum, C. (2009). Pengaruh Sumber Daya Manusia Dan Pemanfaatan Teknologi Informasi Terhadap Keterandalan Dan Ketepatwaktuan Pelaporan Keuangan Pemerintah Daerah Dengan Variabel Intervening Pengendalian Intern Akuntansi (Studi Empiris di Pemda subosukawonosraten) (Doctoral dissertation, UNS (Sebelas Maret University)

Wungow, J. F., Lambey, L., \& Pontoh, W. (2016). Pengaruh tingkat pendidikan, masa kerja, pelatihan dan jabatan terhadap kualitas laporan keuangan pemerintah Kabupaten Minahasa Selatan. Jurnal Riset Akuntansi Dan Auditing" Goodwill", 7(2). 